This is a pre-copyedited, author-produced version of an article accepted for publication in European Law Review following peer review. The definitive published version will be available online on Westlaw UK or from Thomson Reuters DocDel service by the end of 2020.

\title{
When does a communication to the public under EU copyright law need to be to a 'new public'?
}

\section{Eleonora Rosati* \\ Stockholm University}

This article analyses CJEU case law on the notion of 'new public' in the context of the right of communication to the public in EU copyright law, with a focus on Article 3(1) of the InfoSoc Directive. It investigates its origin, use and development, as well as the justifications given for such use. By identifying for the first time four distinct groups of case law, the analysis shows how the role of the 'new public' has changed over time. If intended as a requirement, the 'new public' creates undue complexity in the reasoning of the CJEU in most instances. While others have suggested that the CJEU should disregard this notion altogether, this article proposes a less radical way for the CJEU to 'escape' the difficulties inherent to its own jurisprudence.

Introduction 1

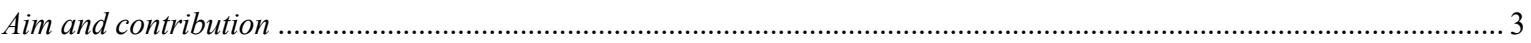

The right of communication to the public in the InfoSoc Directive ................................................................. 4

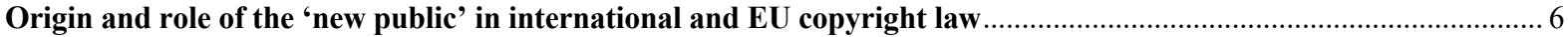

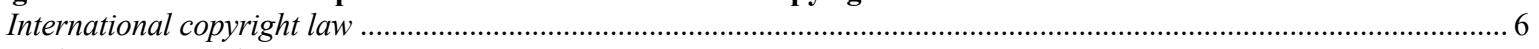

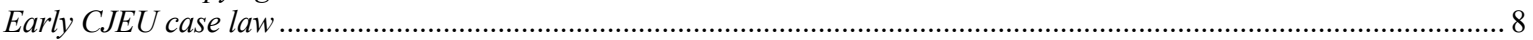

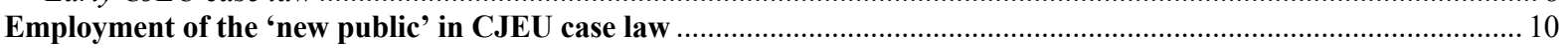

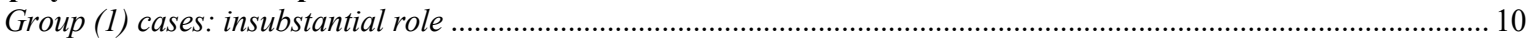

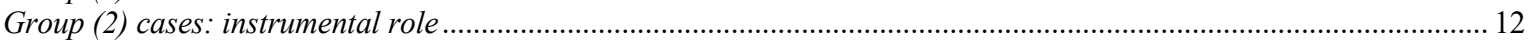

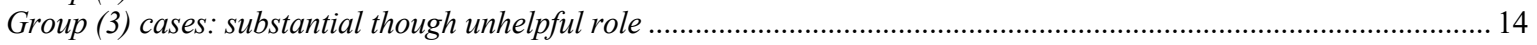

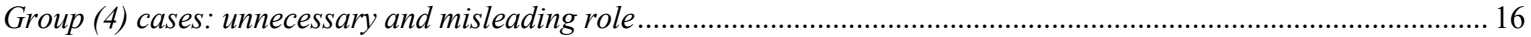

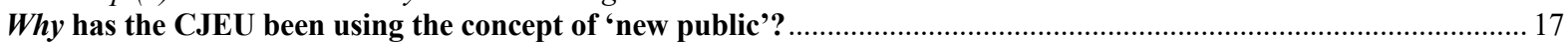

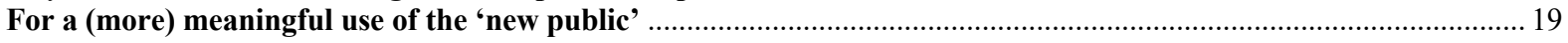

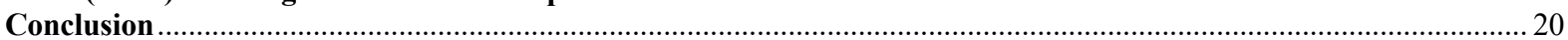

\section{Introduction}

Over the past several years, the right of communication to the public in art. 3(1) of the principal EU directive harmonising the Member States' copyright laws, that is Directive 2001/29' ('InfoSoc Directive'), has progressively and consistently taken centre stage in the EU copyright system. This has been so also given the objective significance of this right ${ }^{2}$, especially - but not solely - in the online

\footnotetext{
* Associate Professor in Intellectual Property Law at Stockholm University. Email: eleonora@e-lawnora.com. This article derives from a study supported by a grant from the International Federation of the Phonographic Industry (IFPI). The Author wishes to thank Professor Lionel Bently, the Editor of European Law Review and the anonymous external reviewer for their helpful feedback on earlier drafts of this contribution. The views and opinions expressed, as well as any errors and omissions, are only the Author's.

${ }^{1}$ Directive 2001/29/EC of the European Parliament and of the Council of 22 May 2001 on the harmonisation of certain aspects of copyright and related rights in the information society [2001] OJ L 167/10 ('InfoSoc Directive').

${ }^{2}$ The same is true of the right of making available to the public in art. 3(2) of the InfoSoc Directive, which is part of the broader right of communication to the public: see C More Entertainment AB v Linus Sandberg (C-279/13) EU:C:2015:199, at [24].
} 
environment. ${ }^{3}$ In turn, this importance is reflected in the great number of referrals (over twenty since the 2006 decision in $S G A E^{4}$ ) to the Court of Justice of the European Union ('CJEU').

EU law does not define the concept of 'communication to the public'. Lacking a definition, the CJEU has sought to determine the meaning and scope thereof in light of the objectives pursued by the InfoSoc Directive, notably that of ensuring a high level of protection of intellectual property. ${ }^{5}$ Like the other economic rights harmonised in the InfoSoc Directive, the right of communication to the public "should be understood in a broad sense". ${ }^{6}$

The two key requirements of art. 3(1) of the InfoSoc Directive are a 'communication' directed at a 'public'. A simple example might be a free-to-air broadcast: the broadcast is an act of communication and it is to the public, because any member of the public with a suitable device can receive the signal and watch/listen to the broadcast. But what if the broadcaster operated online and made available works previously communicated online by the relevant rightholder? Would that activity require a licence? The CJEU has indicated that, when the communication at issue concerns the same works as those covered by the initial communication and is made by using the same technical means (as is the case in the example, since both acts are performed on the internet), it is necessary to determine - not whether the communication at issue qualifies as a communication to the public - but rather whether such communication is to a 'new public'.

By 'new public', the Court intends a public not taken into account by the relevant rightholder when they authorised the initial communication. Although the 'new public' has been part of CJEU jurisprudence since $2006^{7}$, it is a concept that has no statutory basis - whether in international or EU law. As a requirement employed by the CJEU in its case law, the 'new public' has been widely criticised, especially in the aftermath of the 2014 decision in Svensson. ${ }^{8}$ An influential nongovernmental organisation supporting the rights of authors, as well as a number of academics, have considered the 'new public' undesirable, incoherent, and overall contrary to international law.'

\footnotetext{
${ }^{3}$ This is also apparent in light of the ever-increasing relevance of exploitation of protected content through licensed internet streaming rather than through sales of copies (whether in analogue or digital format). In the music sector, for instance, the 2019 figures reveal that internet streaming (both ad-supported streams and subscription audio streams) accounted for $56.1 \%$ of the overall revenues worldwide, while physical sales and downloads (and other digital) accounted for $21.6 \%$ and $7.2 \%$, respectively: see International Federation of the Phonographic Industry, Global Music Report (2020), available at $<$ https://www.ifpi.org/news/en> (last accessed 30 June 2020), p. 11-12. The growing relevance of internet streaming may be also detected in the film sector: the 2019 global figures reveal that online video subscriptions (e.g., to Netflix and Amazon Prime) increased by 28\% when comparing 2019 to 2018: see Motion Picture Association, 2019 THEME Report (2020), available at $<$ https://www.motionpictures.org/wp-content/uploads/2020/03/MPA-THEME-2019.pdf $>$ (last accessed 30 June 2020), p. 34.

${ }^{4}$ Sociedad General de Autores y Editores de España (SGAE) v Rafael Hoteles SA (C-306/05) EU:C:2006:764 ('SGAE').

${ }^{5}$ InfoSoc Directive, recital 24.

${ }^{6} \mathrm{Ibid}$, recital 23.

${ }^{7}$ SGAE, at [40]-[42].

${ }^{8}$ Nils Svensson and Others $v$ Retriever Sverige AB (C-466/12) EU:C:2014:76 ('Svensson'). As it will be explained below at 'Group (3) cases: substantial though unhelpful role', this is probably due to the fact that it was with this decision that the 'new public' gained a decisive role in the assessment of the Court.

${ }^{9}$ See: Association Littéraire et Artistique Internationale, Opinion proposed to the Executive Committee and adopted at its meeting, 17 September 2014 on the criterion "New Public", developed by the Court of Justice of the European Union (CJEU), put in the context of making available and communication to the public (17.9.2014), available at $<$ http://www.alai.org/en/assets/files/resolutions/2014-opinion-new-public.pdf $>$ (last accessed 30 June 2020); P.B. Hugenholtz - S.C. Van Velze, "Communication to a new public? Three reasons why EU copyright law can do without a "new public"" (2016) 47(7) I.I.C. 797; S. Karapapa, "The requirement for a "new public" in EU copyright law" (2017) 42(1) E.L. Rev. 63.
} 


\section{Aim and contribution}

This article investigates the origin of the notion of 'new public', its use and development in the case law of the Court, as well as the justifications given for its use. For the first time, it identifies four distinct groups or phases of decisions in which the concept of 'new public' has been employed in different ways. The analysis details the evolution occurred within CJEU case law and shows how the role of the 'new public' has changed over time. In light of this history, the article agrees with existing scholarship that suggests that the 'new public' creates undue complexity in the reasoning of the CJEU in most instances, with only a limited number of cases, that is (some of) those concerning linking to protected content, in which the notion performs a substantial - yet confusing and overall unhelpful - role.

As mentioned, earlier commentators have also criticised the concept of 'new public'. In their influential 2016 article, Hugenholtz and Van Velze argued that the 'new public' test would be flawed for historical, conceptual and economic reasons alike, and advocated for its removal from the communication to the public analysis. ${ }^{10}$ In her insightful 2017 article, Karapapa referred to the 'new public' as "a sui generis legal fiction, which cannot be understood by reference to other areas of law, even within the contours of intellectual property law, and does not coincide with a commonsensical interpretation of the public."11 Although Karapapa did not suggest removing the concept of 'new public' tout court, she linked the shortcomings caused by the 'new public', which she framed within a licensing dimension, to the allegedly over-broad scope of the right of communication to the public, especially on the internet.

This article shares a significant part of the concerns highlighted by these commentators. However, it does not consider that the right of communication to the public is unduly broad, nor does it suggest that the CJEU should expunge the concept of 'new public' from its analysis altogether, also because - as stated and as we shall see - in most cases the role of the 'new public' has not been key. Whilst the abandonment of the 'new public' might be desirable in principle, it appears difficult to simply eject it from the analysis of the right of communication to the public lacking a proper re-calibration of the role of other components, which this article instead suggests. In addition, it may be unrealistic as an expectation, also considering that the notion of 'new public' has been part of CJEU case law since the very first communication to the public case $(S G A E)$.

The present contribution thus recommends a systematic way to re-focus the role of the 'new public' and, with that, streamline the analysis of communication to the public cases, by shifting the attention from the question of whether the public is 'new' to the question of whether the act of communication to the public is 'new'. If the unauthorised exploitation made by the defendant of protected subjectmatter is independent of or additional to any prior act of communication to the public performed by the rightholder, then prima facie liability may be established insofar as the new communication is to a public.

In sum, this article recommends that: (1) the concept of 'new public' not be regarded as a requirement in cases that involve a new act of communication to the public made by the defendant, irrespective of: (a) whether the technical means used for the initial and the subsequent communication is the same or different, and (b) whether the public targeted by the new act of communication is also new; (2) in retransmission cases, the concept of 'new public' be corrected: it should be considered as an expression of the reasons why the defendant installed physical facilities for enabling or making a communication; (3) the Court acknowledges that the EU liability regime for copyright infringement is one that de facto combines concepts that have traditionally been part of the system of (harmonised) primary liability and concepts that have traditionally been employed in (unharmonised) secondary liability situations.

\footnotetext{
${ }^{10}$ Hugenholtz - Van Velze, “Communication”, cit, fn 9, 811-815.

${ }^{11}$ Karapapa, "The requirement”, cit, fn 9, 81.
} 
Although the analysis mostly focuses on the case law issued in respect of art. 3(1) of the InfoSoc Directive, the findings are generally applicable to the various rights of communication/making available to the public and public performance under EU and national law, including inter alia art. 8 of Directive $2006 / 115^{12}$ (the 'Rental and Lending Rights Directive') and the recently adopted Directive 2019/790 (the 'DSM Directive'). ${ }^{13}$ This is also so because settled CJEU case law indicates that identical concepts in different directives should be attributed the same meaning. ${ }^{14}$ With specific regard to the DSM Directive, it should be additionally noted that the final sentence in recital 64 (referring to art. 17 therein, that is the provision concerning the "Use of protected content by online content-sharing service providers") explicitly states that that directive "does not affect the concept of communication to the public or of making available to the public elsewhere under Union law".

\section{The right of communication to the public in the InfoSoc Directive}

As mentioned, the right of communication to the public has become central to the copyright law discourse. That has been the case at both the EU and national levels. The reason for all this is essentially threefold. First, as stated, the concept of communication to the public is not defined, nor is the content thereof elucidated in any precise way in relevant legislation. Secondly, technological advances and the introduction of new ways to enjoy and exploit protected subject-matter, as well as infringing relevant rights in it have challenged the understanding and application of copyright's exclusive rights. Such challenges are neither necessarily nor solely related to the advent of the internet, as the wealth of case law on the provision of TV and radio sets in different settings clearly demonstrates. Thirdly, as shown in a number of CJEU referrals, identifying the rights engaged by the defendant's activity has not been necessarily a straightforward operation for courts across the EU. The result has been that, upon considering the referred questions, the CJEU has 'corrected' the legal assessment undertaken by the referring courts and reframed the relevant issues as being relevant to different rights than those identified by such courts. ${ }^{15}$ By relying on international sources and a purpose-driven interpretation of the InfoSoc Directive, the CJEU has - as both a necessity and a result - construed the right of communication to the public broadly. ${ }^{16}$

\footnotetext{
12 Directive 2006/115/EC of the European Parliament and of the Council of 12 December 2006 on rental right and lending right and on certain rights related to copyright in the field of intellectual property (codified version) [2006] OJ L 376/28.

${ }^{13}$ Directive (EU) 2019/790 of the European Parliament and of the Council of 17 April 2019 on copyright and related rights in the Digital Single Market and amending Directives 96/9/EC and 2001/29/EC [2019] OJ L 130/92.

${ }^{14}$ For examples specifically in the copyright field, see the CJEU decisions in: Martin Luksan v Petrus van der Let (C-277/10) EU:C:2012:65, at [85]; Football Association Premier League Ltd and Others v QC Leisure and Others (C-403/08) and Karen Murphy v Media Protection Services Ltd (C-429/08) EU:C:2011:631 ('FAPL'), at [187]-[188]; UsedSoft GmbH v Oracle International Corp. (C-128/11) EU:C:2012:407, at [60]; Tobias Mc Fadden v Sony Music Entertainment Germany GmbH (C484/14) EU:C:2016:689, at [36].

${ }^{15}$ Clear examples of this are the referrals which, in this article, are discussed below at 'Group (4) cases: unnecessary and misleading role'. In particular, in Nederlands Uitgeversverbond and Groep Algemene Uitgevers v Tom Kabinet Internet BV and Others (C-263/18) EU:C:2019:1111 ('Tom Kabinet'), the referring court had excluded that the defendant's activity would qualify as communication to the public and asked the CJEU solely to consider the right of distribution and its exhaustion. The Court - instead - found that the matter would fall, first and foremost, within the right of communication to the public; as a result, it conducted its assessment under the lens of art. 3(1) of the InfoSoc Directive (at [28] and [33]-[34]). Similarly, in VCAST Limited v RTI SpA (C-265/16) EU:C:2017:913 ('VCAST'), a case discussed below at 'Group (2) cases: instrumental role', the referring court had framed the relevant activity as one concerning private copying and, thus, reproduction. The CJEU re-qualified the defendant's activity as being relevant to the right of communication to the public and reviewed the situation at hand accordingly (at [18] and [37]).

${ }^{16}$ However, the 'new public' was employed to narrow down the scope of potential liability in Svensson: see below at 'Group (3) cases: substantial though unhelpful role'. For a conceptual framing of the 'new public' concept as a defence to infringement, see S. Karapapa, Defences to Copyright Infringement (Oxford: Oxford University Press, 2020), e-book format, sub Ch. 3 and 5. Also arguing that the 'new public' in Svensson served the CJEU to contain the application of art. 3(1) of the InfoSoc Directive, see: T. Rendas, "Copyright, technology and the CJEU: an empirical study", (2018) 49(2) I.I.C. 153, 181; and C.L. Saw, "Linking on the internet and copyright liability: a clarion call for doctrinal clarity and legal certainty" (2018) 49(5) I.I.C. $536,542-543$.
} 
Turning to the requirements of art. 3(1) of the InfoSoc Directive and starting with the notion of 'act of communication', case law is now solidly oriented in the sense of requiring the mere making available of a copyright work - not also its actual transmission ${ }^{17}$ - in such a way that the persons forming the public may access it, irrespective of whether they avail themselves of such opportunity. ${ }^{18}$ However, where protected subject-matter is made available without it being also transmitted, the CJEU has also indicated the need to consider whether there is a necessary and deliberate intervention on the side of the user/defendant, without which third parties could not readily access the work at issue. More specifically, the user performs an act of communication when they intervene - in full knowledge of the consequences of their action - to give access to a protected work to their customers, and do so, in particular, where, in the absence of that intervention, customers would not, in principle, be able to enjoy the work or would be able to do so only with difficulty. ${ }^{19}$

The 'public', according to the CJEU, in principle refers to an indeterminate and more than de minimis number of people ${ }^{20}$; it thus excludes groups of persons which are too small or insignificant. Elaborating further, the 'public' requires "several unrelated persons". ${ }^{21}$ The Court has also considered the cumulative effect of making a work available to potential recipients. It is thus necessary to consider not just how many persons access the work simultaneously, but also how many may access it in succession. ${ }^{22}$ This said, what or who qualifies as a 'public' still poses interpretative challenges. ${ }^{23}$ As

\footnotetext{
17 This appeared to be the case in: Circul Globus Bucureşti (Circ \& Variete Globus Bucureşti) v Uniunea Compozitorilor şi Muzicologilor din România - Asociaţia pentru Drepturi de Autor (UCMR - ADA) (C-283/10) EU:C:2011:772, at [40]; FAPL, at [190], [193], and [207]; OSA — Ochranný svaz autorský pro práva k dílům hudebním o.s. v Léčebné láznè Mariánské Lázně a.s. (C-351/12) EU:C:2014:110 ('OSA'), at [25]; SBS Belgium NV v Belgische Vereniging van Auteurs, Componisten en Uitgevers (SABAM) (C-325/14) EU:C:2015:764 ('SBS Belgium'), at [16]; and Reha Training Gesellschaft für Sport- und Unfallrehabilitation mbHv Gesellschaft für musikalische Aufführungs- und mechanische Vervielfältigungsrechte eV (GEMA) (C-117/15) EU:C:2016:379 ('Reha Training'), at [38].

${ }^{18}$ SGAE, at [43]; Svensson, at [19]; GS Media BV v Sanoma Media Netherlands BV and Others (C-160/15) EU:C:2016:644 ('GS Media'), at [27]; Stichting Brein v Jack Frederik Wullems, also trading under the name Filmspeler (C-527/15, EU:C:2017:300 ('Filmspeler'), at [36]; Staatlich genehmigte Gesellschaft der Autoren, Komponisten und Musikverleger registrierte Genossenschaft mbH (AKM) v Zürs.net Betriebs GmbH (C-138/16) EU:C:2017:218 ('AKM'), at [20]; Stichting Brein v Ziggo BV and XS4All Internet BV (C-610/15) EU:C:2017:456 ('Ziggo'), at [19]; Land Nordrhein-Westfalen v Dirk Renckhoff (C-161/17) EU:C:2018:634 ('Renckhoff'), at [20]; Tom Kabinet, [37].
}

19 SGAE, at [42]; FAPL, at [194] and [195]; Airfield NV and Canal Digitaal BV v Belgische Vereniging van Auteurs, Componisten en Uitgevers CVBA (Sabam) (C-431/09) and Airfield NV v Agicoa Belgium BVBA (C-432/09) EU:C:2011:648 ('Airfield'), at [79]; Società Consortile Fonografici (SCF) v Marco Del Corso (C-135/10) EU:C:2012:140 ('Del Corso'), at [82]; Phonographic Performance (Ireland) Limited v Ireland and Attorney General, C-162/10, EU:C:2012:141 ('PPL'), at [31]; Reha Training, at [46]; GS Media, at [35]; Filmspeler, at [31]; Ziggo, at [26]. On the progressive relaxation of what qualifies as indispensable/essential intervention in CJEU case law (in particular: GS Media, at [43] and [48]-[55]; Filmspeler, at [41]; and Ziggo, at [36]), see E. Rosati, "What does the European Commission make of the EU copyright acquis when it pleads before the CJEU? The Legal Service's Observations in digital/online cases” (2020) 45(1) E.L. Rev. 67, 77 and 93.

20 SGAE, at [38]; Del Corso, at [84]; PPL, at [33]; ITV Broadcasting Ltd and Others v TVCatchUp Ltd (C-607/11) EU:C:2013:147 ('ITV'), at [32]; Svensson, at [21]; OSA, at [27]; Sociedade Portuguesa de Autores CRL v Ministério Público and Others (C-151/15) EU:C:2015:468, at [19]; SBS Belgium, at [21]; GS Media, at [36]; Filmspeler, at [45]; AKM, at [24]; Ziggo, at [27] and [42]; Tom Kabinet, at [66].

${ }^{21}$ Tom Kabinet, at [67]. By referring to analogy to Vereniging Openbare Bibliotheken v Stichting Leenrecht (C-174/15) EU:C:2016:856, in that decision, the Court also noted (at [69]) that there would be no 'public' if a platform made only available a single copy of protected subject-matter to a specified user at any given time, and such copy became unusable by that user after the relevant period has expired. On this point, see A. Morgan - P. Abbott - C. Stothers, "ECJ rules that the sale of secondhand e-books infringes copyright" (2020) 15(4) J.I.P.L.P. 236, 237, observing that this part of the judgment "leaves open the possibility that a system with proper digital rights management, robust enough to limit the communication of an e-book to one person at any given time, might not be regarded as a communication to the public".

${ }^{22}$ Ziggo, at [41] and case law cited therein.

${ }^{23}$ For instance, in Föreningen Svenska Tonsättares Internationella Musikbyrå u.p.a. (Stim) and Svenska artisters och musikers intresseorganisation ek. för. (SAMI) v Fleetmanager Sweden AB and Nordisk Biluthyrning (C-753/18) EU:C:2020:268 ('STIM and $S A M I^{\prime}$ ), one of the questions referred to the CJEU was whether the volume and characteristics of the defendant's business activity (car rental companies and the duration of individual car rentals) would be relevant to the determination of whether there is an act of communication to the public. Holding in the negative, see Opinion of Advocate General Szpunar in Föreningen Svenska Tonsättares Internationella Musikbyrå u.p.a. (Stim) and Svenska artisters och musikers 
mentioned, in the case of a communication concerning the same works as those included in the initial communication and made by the same technical means, the CJEU has stated that the communication must be directed at a 'new public'.

Besides the requirements of an 'act of communication' to a 'public', the CJEU has also highlighted the need to consider additional criteria, which are not autonomous and are interdependent, and may - in different situations - be present to widely varying degrees. Such criteria must be applied both individually and in their interaction with one another. ${ }^{24}$ So, in GS Media, the CJEU inter alia relied on the 'profit-making nature' of the communication at issue to determine the potential liability of a link provider for the posting of links to unlicensed content. Prior to that decision, the profit-making nature of the communication, although referred to as early as in $S G A E^{25}$, had not been given the centrality that it did instead acquire in that case: in Reha Training, for instance, the Grand Chamber of the CJEU considered that this criterion, while not irrelevant, would not be however decisive. ${ }^{26}$ In GS Media, instead, the Court adopted a rebuttable presumption that a person who links to protected content for profit has undertaken the necessary checks to ensure that the work linked to was not illegally published. ${ }^{27}$

\section{Origin and role of the 'new public' in international and EU copyright law}

\section{International copyright law}

One of the interpretative standards employed by the CJEU is the one concerning interpretation of EU provisions in light of international instruments. The Court has often relied on international instruments ${ }^{28}$ to undertake the proper reading of EU law, including the InfoSoc Directive. ${ }^{29}$ The latter was inter alia adopted to implement the 1996 WIPO Internet Treaties ${ }^{30}$ into the EU legal order. In turn, art. 1(2) of the WIPO Copyright Treaty ('WCT') requires compliance with arts. 1 to 21 of the Berne Convention. At the international level, the right of communication to the public indeed received its first formulation in art. 11bis of the Berne Convention, as adopted in 1928 and later revised with the Brussels Act 1948. The WCT supplemented the Berne Convention, and introduced the concept of 'making available to the public' in its art. 8.

Like EU law, international copyright instruments - including the WCT and the WIPO Performances and Phonograms Treaty ('WPPT'), as well as the patchwork of rights in arts. 11(1)(ii), 11bis(1)(i) and (ii), 11ter(1)(ii), 14(1)(ii) and 14bis(1) of the Berne Convention and arts. 7(1)(a), 12, and 13(d) of the Rome Convention - make no mention of the concept of 'new public'. ${ }^{31}$ The origin of the concept of

intresseorganisation ek. för. (SAMI) v Fleetmanager Sweden AB and Nordisk Biluthyrning AB (C-753/18) EU:C:2020:4, at [50]-[55]. In the resulting decision, the CJEU did not consider it necessary to answer this question, having concluded that the activity at issue would not constitute an act of communication: STIM and Sami, at [39]-[40].

${ }^{24}$ Del Corso, at [79]; PPL, at [30]; Reha Training, at [35]; GS Media, at [34]; Filmspeler, at [30]; Ziggo, at [25].

${ }^{25} S G A E$, at [44].

${ }^{26}$ Reha Training, at [49], referring to ITV, at [43], and FAPL, at [204].

${ }^{27}$ GS Media, at [51]. The operation of this presumption was confirmed in the subsequent ruling in Filmspeler, at [49] and [51], and arguably also in Ziggo, as discussed in E. Rosati, "The CJEU Pirate Bay judgment and its impact on the liability of online platforms" (2017) 39(12) E.I.P.R. 737, 743-744. See contra C. Angelopoulos, "Communication to the public and accessory copyright infringement" (2017) 76(3) C.L.J. 496, 498.

${ }^{28}$ Though not solely legislative instruments: in $P P L$, for instance, the Court referred (at [34]) to the Glossary of the World Intellectual Property Organization ('WIPO') to elucidate the concept of communication to the public.

${ }^{29}$ See further E. Rosati, Copyright and the Court of Justice of the European Union (Oxford: Oxford University Press, 2019), p. 54-55.

${ }^{30}$ InfoSoc Directive, recital 15 . The phrase 'WIPO Internet Treaties' refers jointly to the WIPO Copyright Treaty ('WCT') and the WIPO Phonograms and Performances Treaty ('WPPT').

${ }^{31}$ On this see, ex multis, J. Reinbothe - S. von Lewinski, The WIPO Treaties on Copyright: A Commentary on the WCT, the $W P P T$, and the BTAP (Oxford: OUP, 2015), §7.8.17. 
'new public' in CJEU case law is thus to be traced back not to international legislative instruments, but rather to the interpretation thereof, notably in the 1978 WIPO Guide to the Berne Convention ("1978 Guide') authored by Claude Masouyé, the then Director of the Copyright and Public Information Department of the International Bureau of WIPO. The 1978 Guide is an article-by-article commentary to the Berne Convention - as lastly revised with the Paris Act (1971) - and was not intended as an authentic interpretation thereof. ${ }^{32}$ There, the concept of 'new public' is employed in relation to art. 11bis(1) of the Berne Convention.

This provision is devoted to "broadcasting and related rights". Art. 11bis(1)(i) sets out the right to authorise the broadcasting of a work and the communication thereof to the public by any other means of wireless diffusion of sign, sounds or images. Art. 11bis(1)(ii) concerns the right in respect of subsequent uses of such communication by an organisation other than the original one. Art. 11bis(1)(iii) relates to the right to authorise the public communication of the broadcast by loudspeaker or on a television screen. Such rights, which are now all included under the aegis of art. $8 \mathrm{WCT}^{33}$, are "not mutually exclusive but cumulative". ${ }^{34}$

The 1978 Guide specifically refers to the 'new public' in relation to art. 11(1)bis(iii), in respect of which it seeks to distinguish between a performance of a broadcasted work to a private circle of family and friends (which would not fall under the scope of the provision) and a wider performance, which the rightholder had not contemplated when they licensed use of their broadcast. It however appears that this inherent logic, that is the underlying norm that may justify the reference - in the 1978 Guide - to the notion of 'new public', informs part of (ii), i.e. rebroadcasting ${ }^{35}$, and (iii). In both instances, the use made of the broadcast reaches a public other than that contemplated by the author when they gave their original permission. The assumption is that the author "thinks of his licence to broadcast as covering only the direct audience receiving the signal within the family circle" ${ }^{36}$ The idea underpinning the "new public' is whether the user has exceeded the scope of the licence by reusing the broadcast/reaching a public other than the intended audience. Only where this is not the case, the use at hand does not require the authorisation of the relevant rightholder. In situations falling under art. 11bis(1)(i), the assessment is different: the provision concerns the initial communication of a work, not its subsequent use. According to the 1978 Guide, "[w] hat matters is the emission of signals". ${ }^{37}$

In the period between the adoption of the InfoSoc Directive in 2001 and the referral in SGAE in 2005, the WIPO published a new Guide to four conventions - including the Berne Convention - and two treaties administered by WIPO ('2003 Guide'). It was authored by Mihály Ficsor, who - between 1985 and 1999 - had been, first, Director and, then, Assistant Director General of WIPO and had had an important role in the negotiation and adoption of the 1996 WIPO Internet Treaties. Also an article-byarticle commentary to inter alia the Berne Convention, the 2003 Guide does not contain any reference to the concept of 'new public'. The 2003 Guide was conceived as a "new publication" and not "an

\footnotetext{
${ }^{32}$ C. Masouyé, Guide to the Berne Convention for the Protection of Literary and Artistic Works (Paris Act, 1971) (Geneva: WIPO, 1978) ('1978 Guide'), p. 4.

33 The WCT leaves the Berne provision unaffected whilst going beyond it in scope. See S. von Lewinski - M.M. Walter, "Information Society Directive", in S. von Lewinski - M.M. Walter, European Copyright Law (Oxford: Oxford University Press, 2010), §11.3.12.

${ }^{34} 1978$ Guide, §11bis.14.

${ }^{35}$ See SGAE, at [40]. M.F. Makeen, "The controversy of simultaneous cable retransmission to hotel rooms under international and European copyright laws" (2010) 57 J. Copyright Soc'y U.S.A. 59, 62-64, argues that the legislative history of art. 11 bis(1)(ii) suggests that the 'new public' was rejected in respect of simultaneous cable retransmission and replaced by the criterion of 'organisation other than the original one'.

361978 Guide, §11bis.12. S. von Lewinski, International Copyright Law and Policy (Oxford: Oxford University Press, 2008), $\S 5.147$, notes that, however, "not any family circle can be considered to be private".

${ }^{37} 1978$ Guide, §11bis.3.
} 
update or adaptation" of the 1978 Guide and was not meant to replace it, but rather to "join it" ${ }^{38}$ In relation to art. 11bis(1)(ii), the 2003 Guide states that the decisive requirement for the application of that right is that:

the communication is made by an organization other than the original one; if this is the case, the author or other owner of copyright has a right separate from the right to authorize the original act of broadcasting. There is no basis in the text of the Convention for which it would be justified at all to consider theories according to which "any" such communication only means "some". 39

Thus, what would be required is solely consideration of whether there is a new act of communication to the public, that is an activity that goes beyond the concept of reception of a broadcast. ${ }^{40}$ In other words: not whether the communication made by an organisation other than the original one is directed at a 'new public', but rather whether the activity in question may be regarded as a 'new communication' to the public. With reference to art. 11bis(iii), the 2003 Guide suggests that use of the term 'public communication' instead of 'communication to the public' means that this act does not involve the transmission of the work to another place: it is an act carried out in a place where the public is or may be present, and, in that sense, it is similar to public performance and to public recitation. ${ }^{41}$

\section{Early CJEU case law}

The first mention of the 'new public' dates back to 1999, when Advocate General ('AG') La Pergola referred to it and the 1978 Guide in his Opinion in EGEDA, a case concerning the interpretation of art. 1(2)(a) and (3) of Council Directive 93/83 (the 'Satellite and Cable Directive'). This referral had been made in the context of proceedings relating to the unlicensed distribution, by a hotel operator, of protected subject-matter incorporated in TV broadcasts and phonograms, which had been provided to the guests of a hotel by means of TV sets that it had installed. The question for the CJEU was whether the activity performed by the hotel operator required the consent of the rightholders represented by collecting society EGEDA. ${ }^{43}$

Relying on the 1978 Guide, AG La Pergola adopted an economic view of the meaning of 'new public': an author should be entitled to control any so-called 'secondary' uses of their subject-matter when such uses result in an "independent economic exploitation for financial profit by the person responsible" for them. ${ }^{44}$ Whilst the making available by the receiver of a broadcast to their family circle and friends would not involve an economic exploitation of the works contained in a broadcast, the same would not

${ }^{38}$ M. Ficsor, Guide to the Copyright and Related Rights Treaties Administered by WIPO and Glossary of Copyright and Related Rights Terms (Geneva: WIPO, 2003) ('2003 Guide'), 'Acknowledgment'.

${ }^{39}$ Ibid, BC-11bis.14.

${ }^{40}$ Ibid, BC-11bis. 15.

${ }^{41} \mathrm{Ibid}, \mathrm{p} .305$.

42 Council Directive 93/83/EEC of 27 September 1993 on the coordination of certain rules concerning copyright and rights related to copyright applicable to satellite broadcasting and cable retransmission [1993] OJ L 248/15 ('Satellite and Cable Directive').

${ }^{43}$ The resulting judgment in Entidad de Gestión de Derechos de los Productores Audiovisuales (Egeda) v Hostelería Asturiana SA (Hoasa) (C-293/98) EU:C:2000:66 did not engage with the concept of 'new public', finding instead that the question referred by the national court, that is whether the reception by a hotel establishment of satellite or terrestrial television signals and their distribution by cable to the various rooms of that hotel would be an 'act of communication to the public' or 'reception by the public', is not something governed by the Satellite and Cable Directive, with the result that the matter would have to be decided in accordance with national law. This was the case prior to the adoption of the InfoSoc Directive which, instead, covers situations like those at issue in EGEDA.

${ }^{44}$ Opinion of Advocate General La Pergola in Entidad de Gestión de Derechos de los Productores Audiovisuales (Egeda) $v$ Hostelería Asturiana SA (Hoasa) (C-293/98) EU:C:1999:403 ('EGEDA AG’), at [24]. 
be true of a hotel that makes a broadcast (and consequently the works transmitted by the broadcast) available to its clientele:

it is common knowledge that the inclusion of a cable television retransmission service in the services a hotel offers its clients, together with the number of channels available, is one of the normal criteria used to classify hotels by category and thus affects the prices they can charge. ${ }^{45}$

The 'new public' requirement made its appearance in the very first judgment concerning the interpretation of art. 3(1) of the InfoSoc Directive: SGAE. In her Opinion in that referral, AG Sharpston held that art. 11bis of the Berne Convention means that the author whose work is included in a broadcast has the right to authorise any retransmission of their broadcast where this procures a fresh circle of people, that is when such retransmission reaches a new public. ${ }^{46}$ It follows that:

[t] he transmission of broadcasts to hotel bedrooms by means of television sets to which is fed a signal initially received by the hotel falls squarely within that concept. ${ }^{47}$

Similarly to AG La Pergola but differently from him in the sense of framing the situation at hand within an art. 11bis(1)(ii) instead of (iii) scenario ${ }^{48}$, AG Sharpston shared the view that the economic significance of the retransmission at issue is to be taken into account. Nonetheless, the AG referred said significance to the author of the work included in the broadcast, rather than the organisation performing such act. $^{49}$

When the Court issued its ruling in that case, the 'new public' officially became part of the analysis under art. 3(1) of the InfoSoc Directive:

a communication made in circumstances such as those in the main proceedings constitutes, according to art. 11bis(1)(ii) of the Berne Convention, a communication made by a broadcasting organisation other than the original one. Thus, such a transmission is made to a public different from the public at which the original act of communication of the work is directed, that is, to a new public. ${ }^{50}$

Over time, what might have appeared - at first - like a small jurisprudential seed has instead produced a vast quantity of cases: the CJEU has referred to the concept of 'new public' in the vast majority of its decisions concerning the right of communication to the public. The concept of 'new public', however, is not monolithic and the way in which the CJEU has employed it has evolved. By reviewing the different role played by the 'new public' concept in all the decisions referring to it for the sake of determining whether the activity at hand would fall within the scope of copyright protection, four

\footnotetext{
${ }^{45} \mathrm{Ibid}$, at [25].

${ }^{46}$ Opinion of Advocate General Sharpston in Sociedad General de Autores y Editores de España (SGAE) v Rafael Hoteles SA (C-306/05) EU:C:2006:479 ('SGAE AG'), at [50].

${ }^{47} \mathrm{Ibid}$, at [52].

${ }^{48} \mathrm{Ibid}$, at [48]. Cf EGEDA AG, at [20]. According to AG Sharpston (SGAE AG, at [50]):
}

the criterion of communication 'by an organisation other than the original one', used in art. 11bis(1)(ii) of the Convention, was adopted as a 'purely functional' distinction: the option of requiring a fresh authorisation wherever a retransmission 'procured a fresh circle of listeners' was deliberately rejected. None the less, that seems to be the essence of the provision's effect.

This article agrees with the position of AG Sharpston, but Hugenholtz - Van Velze, "Communication", cit, fn 9, 803 consider this part of the Opinion a "mis-interpretation" on the side of the AG.

${ }^{49} S G A E \mathrm{AG}$, at [54]. Cf EGEDA AG, at [24].

${ }^{50} S G A E$, at [40]. 
different groups of decisions in the case law that refers to 'new public' may be identified, which - in turn - correspond to four different, historical phases of this concept ${ }^{51}$ :

- Group (or phase) (1) consists of judgments in the field of broadcasting and public performance. ${ }^{52}$

- Group (or phase) (2) comprises rulings in which the consideration of the technical means used was pivotal to the 'new public' assessment, the first being the decision in ITV. ${ }^{53}$

- Group (or phase) (3) consists of decisions rendered in situations in which the defendant gave access, through clickable links, to works previously communicated to the public by third parties. $^{54}$

- Group (or phase) (4) relates to decisions in which the defendant's activity consisted of an independent act of communication to the public on the internet of third-party protected subjectmatter. $^{55}$

As it will be discussed in what follows, reliance by the CJEU on the 'new public' requirement - though not always consistently in each group/phase - may be considered: insubstantial insofar as group (1) cases are concerned; instrumental in group (2) cases; substantial though overall unhelpful insofar as group (3) cases are concerned; and unnecessary and misleading with regard to group (4) cases.

\section{Employment of the 'new public' in CJEU case law}

\section{Group (1) cases: insubstantial role}

In $S G A E$, the CJEU referred to the concept of 'new public' for the first time. It is significant that, at this stage, the concept of 'new public' was not deployed as a requirement for a finding that an act of communication to the public had taken place, but was rather a consequence of the activity of the user/defendant, which was also motivated by a profit-making intention. ${ }^{56}$ The making available of TV sets in the guest rooms of a hotel was considered a communication falling "squarely" within art. 11bis(1)(ii) of the Berne Convention:

As is explained in the Guide to the Berne Convention, [...] when the author authorises the broadcast of his work, he considers only direct users, that is, the owners of reception equipment who, either personally or within their own private or family circles, receive the programme. According to the Guide, if reception is for a larger audience, possibly for profit, a new section of the receiving public hears or sees the work and the communication of the programme via a loudspeaker or analogous instrument no longer constitutes simple reception of the programme itself but is an independent act through which the broadcast work is communicated to a new

\footnotetext{
${ }^{51}$ Some commentators have referred to certain decisions, notably those in Reha Training and GS Media, as "sui generis groups of communication to the public cases" (B. Clark - S. Tozzi, ""Communication to the public" under EU copyright law: an increasingly Delphic concept or intentional fragmentation?" (2016) 38(12) E.I.P.R. 715, 715; B. Clark - J. Dickenson, "Theseus and the labyrinth? An overview of "communication to the public" under EU copyright law: after Reha Training and GS Media where are we now and where do we go from here?" (2017) 39(5) E.I.P.R. 265, 271). This article rejects the idea of 'sui generis' decisions, in that similar approaches are detectable between the groups of cases identified herein.

${ }^{52}$ SGAE; Organismos Sillogikis Diacheirisis Dimiourgon Theatrikon kai Optikoakoustikon Ergon v Divani Akropolis Anonimi Xenodocheiaki kai Touristiki Etaireai (C-136/09) EU:C:2010:151 ('Divani'); Airfield; PPL; FAPL; OSA; Reha Training. Even if there is no express mention of the 'new public', Del Corso is also a decision that is relevant to this group of cases because it shows how, in this phase, the fact that there is a 'new public' is a consequence of the role of the user and the effect of the use.

${ }^{53}$ The decisions in SBS Belgium, AKM, Filmspeler, Ziggo, and VCAST are part of this group.

${ }^{54}$ This group includes the decisions in: Svensson; BestWater International GmbH v Michael Mebes and Stefan Potsch (C348/13) EU:C:2014:2315 ('BestWater'); and GS Media.

55 They are the judgments in Renckhoff and Tom Kabinet.

56 The relevance of the user's profit-making intention in $S G A E$ has raised uncertainties among commentators: see K. Klafkowska-Waśniowska, "Public communication right: towards the full harmonisation?" (2013) 35(12) E.I.P.R. 751, 754.
} 
public. As the Guide makes clear, such public reception falls within the scope of the author's exclusive authorisation right.

The clientele of a hotel forms such a new public. The transmission of the broadcast work to that clientele using television sets is not just a technical means to ensure or improve reception of the original broadcast in the catchment area. On the contrary, the hotel is the organisation which intervenes, in full knowledge of the consequences of its action, to give access to the protected work to its customers. In the absence of that intervention, its customers, although physically within that area, would not, in principle, be able to enjoy the broadcast work. ${ }^{57}$

The Court concluded that there is a communication to the public when the communication at hand is performed by an organisation other than the original one, which - in doing so and to use the words of AG La Pergola - pursues an "independent economic exploitation for financial profit". This conclusion also follows from awareness that, as required under recital 23 in the preamble to the InfoSoc Directive, the concept of 'communication to the public' must be interpreted broadly. Although this consideration was not crucial to the Court's findings in this case, what is relevant is that the user/defendant makes third-party protected subject-matter available to the public: the public is 'new' because of the independent economic exploitation at issue.

The reasoning followed in $S G A E$ was also substantially employed in other broadcasting and public performance cases: Divani $^{58}$ (again, making available of TV sets in hotel guest rooms); FAPL ${ }^{59}$ (making available of TV sets in public houses); Airfield ${ }^{60}$ (satellite communications under the Satellite and Cable Directive); $P P L^{61}$ (provision of TVs and/or radios in guest bedrooms and qualification thereof under the Rental and Lending Rights Directive); and, more recently, $O S A^{62}$ (making available of radio and TV sets in the guest rooms of spa establishments) and Reha Training ${ }^{63}$ (making available of TV sets in a rehabilitation centre).

In group (1) cases, the type of assessment required to determine whether a certain activity is to be regarded as an act of communication to the public revolved around the role of the user/defendant: such role must consist of giving access to protected subject-matter with awareness of the resulting consequences, i.e. to undertake an independent economic exploitation that reaches a public other than direct viewers. A contrario, in Del Corso, the CJEU excluded that the playing of a broadcast containing phonograms in a dentist's waiting room would qualify as communication to the public (under Directive $92 / 100^{64}$ ) also because such activity, on the side of a dentist, would not increase the number of patients or the price of the treatment that they provide. As such, according to the Court, there would be no impact on their income. ${ }^{65}$ The Del Corso decision is somewhat inconsistent with the rest of the Court's case law because it gives the 'profit-making nature' criterion the determinative role. ${ }^{66}$ Overall, for this group

${ }^{57} S G A E$, at [41]-[42].

${ }^{58}$ Divani, at [36]-[39].

${ }^{59}$ FAPL, at [195]-[198].

${ }^{60}$ Airfield, at [76]-[80].

${ }^{61} \mathrm{PPL}$, at [40]-[44].

${ }^{62} \mathrm{OSA}$, at [31]-[32].

${ }^{63}$ Reha Training, at [45]-[47].

${ }^{64}$ Council Directive 92/100/EEC of 19 November 1992 on rental right and lending right and on certain rights related to copyright in the field of intellectual property [1992] OJ L 346/61.

${ }^{65}$ Del Corso, at [97].

${ }^{66}$ The Del Corso decision justified the request to assign the subsequent Reha Training referral to the Grand Chamber of the CJEU. As explained by Daniel Segoin (a former legal adviser and French representative to the CJEU in the Ministry of Foreign Affairs), the intention on the side of the French government was to instigate a change in the case law concerning the 'new public' and to clarify whether the for-profit criterion should be taken into account: see D. Segoin, "Une perspective gouvernementale française sur la jurisprudence récente de la CJUE en matière de propriété littéraire et artistique" (2020) 263 R.I.D.A. Jan 2020, §2.A. 
of cases, it was the twofold consideration of the role of the user and the effect of the use that served to determine whether the communication at hand would be in fact a communication to the public: the fact that there is a new public is a consequence of such role and effect.

\section{Group (2) cases: instrumental role}

The second group of the 'new public' case law originates from ITV. This decision set a new course for the application of the right in art. 3(1) of the InfoSoc Directive, in that it was subsequently interpreted as mandating consideration of the 'new public' as a requirement under that provision ${ }^{67}$ The background national proceedings concerned a situation in which defendant TV CatchUp's unlicensed activity was not targeted at any public other than the one originally envisaged by the relevant rightholders. TV CatchUp offered those already entitled to view free-to-air TV broadcasts in the UK the possibility to receive, via the internet, live streams of such broadcasts. TV CatchUp made sure to restrict use of its services, which were funded by advertising, to the UK through a facility that would authenticate users' location and refuse access to those not already entitled to view the terrestrial broadcasts.

The referring court had asked the CJEU to clarify whether a retransmission like the one at hand would qualify as a communication to the public under art. 3(1) of the InfoSoc Directive. The CJEU answered in the affirmative, albeit that - to reach this conclusion - the Court deemed it necessary to take into account the $S G A E$-derived 'new public' concept, as if that was a general requirement under that provision. In so doing, the CJEU 'distinguished' the matter at hand from that in SGAE, FAPL and Airfield, and ruled that:

the situations examined in the cases which gave rise to the abovementioned judgments differ clearly from the situation at issue in the case in the main proceedings. In those cases, the Court examined situations in which an operator had made accessible, by its deliberate intervention, a broadcast containing protected works to a new public which was not considered by the authors concerned when they authorised the broadcast in question.

By contrast, the main proceedings in the present case concern the transmission of works included in a terrestrial broadcast and the making available of those works over the internet [...] [E] ach of those two transmissions must be authorised individually and separately by the authors concerned given that each is made under specific technical conditions, using a different means of transmission for the protected works, and each is intended for a public. In those circumstances, it is no longer necessary to examine $[\ldots]$ the requirement that there must be a new public". ${ }^{68}$

The error, on the side of the CJEU (especially considering the subsequent interpretation given of this ruling), was twofold: first, as stated, to consider the 'new public' referred to in $S G A E$ as a general, substantive requirement for a finding of infringement (as explained, it was not) ${ }^{69}$; secondly, not to make it sufficiently clear that, in Berne terms, the situation at issue was not comparable to $S G A E$, i.e. one concerning the subsequent use of an existing communication. Rather, the one at issue was a new emission tout court, which also happened to use different technical means from the communication originally made by the claimants.

\footnotetext{
${ }^{67}$ Also arguing in this sense, see J. Koo, "Away we Ziggo: the latest chapter in the EU communication to the public story" (2018) 13(7) J.I.P.L.P. 542, 542.

${ }^{68} \mathrm{ITV}$, at [38]-[39].

${ }^{69}$ See also Karapapa, "The requirement”, cit, fn 9, 69.
} 
The same reasoning of ITV was adopted in SBS Belgium ${ }^{70}$, Filmspeler ${ }^{71}$, Ziggo $^{72}$, and $V C A S T^{73}$, that is all cases in which new acts of communication to the public had been performed by the defendants. In particular, VCAST was a case concerning the unauthorised making available, by the defendant, of a cloud-based recording service that allowed its customers to make copies of terrestrial TV programmes, irrespective of whether such customers could lawfully access the relevant broadcasts terrestrially. By reframing the referral as being relevant, first and foremost, to the right of communication/making available to the public rather than private copying under art. 5(2)(b) of the InfoSoc Directive (as the national court had instead considered it to be the case), the Court concluded that the defendant's transmissions would constitute communications to different publics. As a result, each of them should be subjected to the relevant rightholders' consent. It would not be necessary to examine whether the publics targeted by those communications are identical or whether the public targeted by defendant constitutes a new public. ${ }^{74}$

The analysis in VCAST was seemingly consistent with case law preceding it in the sense that, if there is a new communication, there is no need to consider if the public at which this is directed is also 'new'. However, it problematically suggests a reading of ITV according to which the technical means used in the original and the defendant's communication must be different for there to be a new communication that does not require consideration of whether the targeted public is 'new' ${ }^{75}$ The approach in VCAST became particularly problematic in subsequent case law, as the decisions belonging to group (4) in particular demonstrate.

Also the slightly ambiguous ruling in $A K M$ belongs to this group of cases. In that instance the CJEU, having concluded that the technical means used for the original and the defendant's communication was different, still deemed it necessary to determine whether the communication at hand would be to a new public. ${ }^{76}$ At first sight it might appear that, in $A K M$, the CJEU wished to take a different approach to the one in ITV because it considered the 'new public' even if the technical means used was different. However, this was not the case. As AG Szpunar explained in his Opinion in France Télévisions, the finding of the Court in $A K M$ rests on the fact that the relevant rightholders "had indeed taken into account the retransmission at issue when authorising the original broadcast." change the rule set in ITV, but merely applied it in light of the particular factual background of the case, including that the exploitation in question would be a retransmission and not an act of exploitation that would go beyond what the rightholder had originally contemplated.

Overall, with group (2) cases, the legal treatment initially adopted in group (1) cases changed. In light of the Court's own case law, whether there is a communication to a public other than the one originally envisaged by the rightholder should only be considered when the communication by the user/defendant uses the same technical means as the original communication. This approach is both arbitrary and problematic, as it subsequently became apparent in cases concerning online uses of protected content. As it will be elaborated below, in those instances, the CJEU regarded the 'new public' as a requirement

\footnotetext{
${ }^{70}$ SBS Belgium, at [17]-[19].

${ }^{71}$ Filmspeler, at [35]-[38].

${ }^{72}$ Ziggo, at [30]-[31].

${ }^{73} \mathrm{VCAST}$, at [40]-[43] and [46].

${ }^{74} \mathrm{Ibid}$, at [50].

${ }^{75}$ Also proposing a critical reading of this part of the judgment, see J.P. Quintais - T. Rendas, "EU copyright law and the Cloud: VCAST and the intersection of private copying and communication to the public" (2018) 13(9) J.I.P.L.P. $711,715$.

${ }^{76} A K M$, at [23]-[26].

${ }^{77}$ Opinion of Advocate General Szpunar in France Télévisions SA v Playmédia and Conseil supérieur de l'audiovisuel (CSA) (C-298/17) EU:C:2018:535, at [47], referring to $A K M$, at [28]-[29] and first point of the operative part of that judgment. Prior to this, in the same sense, see also Opinion of Advocate General Szpunar in VCAST Limited v RTI SpA (C-265/16) EU:C:2017:649, at [52]. Quintais - Rendas, "EU copyright", cit, fn 75, 718, observe that the CJEU in VCAST substantially, though implicitly, agreed with the AG on this point.
} 
for/element of 'communication to the public'. This had two consequences: on the one hand, it prompted the Court to rely on other requirements and criteria in order to mitigate or avoid the harshest and paradoxical ${ }^{78}$ consequences of the 'new public' (group (3) cases); on the other hand, it led the Court to consider it even when it should have not and, in so doing, compelled it to find unduly complex ways to 'escape' the consequences of its application (group (4) cases).

\section{Group (3) cases: substantial though unhelpful role}

In group (3), the 'new public' formed an essential part of the Court's reasoning, at least in Svensson. This referral presented the Court with the first opportunity to determine whether and at what conditions the posting on the internet of a clickable link (hyperlink) to protected subject-matter falls within the scope of copyright protection. The background proceedings had been brought by a group of journalists who had consented to the publication, on the website of the Göteborgs-Posten newspaper, of articles that they had authored. The articles were freely accessible on that website. The litigation was directed at a website operator that provided its clients, according to their needs, with lists of clickable links to articles published on third-party websites, including that of the Göteborgs-Posten. The claimants sought compensation on the ground that the defendant had made use, without their authorisation, of their works by making them available to its clients through clickable links. The CJEU ruled that the provision of a clickable link to a protected work is to be regarded as an act of communication to the public within art. 3 (1) of the InfoSoc Directive when the link at issue makes that work available to a 'new public'. ${ }^{79} 80$

In reaching this conclusion, the CJEU found that an act of communication concerning the same works as those covered by the initial communication and made by the same technical means (internet) will require a licence if it is directed at a public that was not taken into account by the relevant rightholder when they authorised the initial communication to the public, that is a "new public. ${ }^{81}$ The provision of a clickable link to a work initially made available with the consent of the rightholder and technically ${ }^{82}$ freely accessible on a third-party website does not fall within the scope of application of art. 3(1) of the InfoSoc Directive, because the public targeted by the initial communication consists of all potential visitors to the concerned site. As such, the Court concluded, in such a situation the link would not communicate the work to a new public. ${ }^{83}$

\footnotetext{
${ }^{78}$ As already noted above at fn 16 and discussed further below at 'Group (3) cases: substantial though unhelpful role', the 'new public' was initially employed in Svensson to 'contain' liability for unauthorised linking to protected works.

${ }^{79}$ Prior to this decision, cf. the positions adopted by von Lewinski - Walter, "Information Society", cit, fn 33, $\S 11.3 .35$ and European Copyright Society, Opinion on the Reference to the CJEU in Case C466/12 Svensson (15.02.2013), available at $<$ https://europeancopyrightsocietydotorg.files.wordpress.com/2015/12/european-copyright-society-opinion-on-svenssonfirst-signatoriespaginatedv31.pdf $>$ (last accessed 30 June 2020).

${ }^{80}$ It remains uncertain whether the same reasoning might be applied to links other than hyperlinks. Cf M. Leistner, "Copyright law on the internet in need of reform: hyperlinks, online platforms and aggregators" (2017) 12(2) J.I.P.L.P. 136, 138-139, submitting that not all links should be treated the same, and that the provider of a framed link should be under more than a merely minimal duty to check that the content at issue was published with the consent of the rightholder. For linking that involves embedding/framing, also issues of reproduction - which the CJEU has not yet specifically addressed (the pending referral in VG Bild-Kunst v Stiftung Preußischer Kulturbesitz (C-392/19) concerns framed links in the context of the right of communication to the public in art. 3(1) of the InfoSoc Directive) - would likely come into consideration. For a discussion of linking and the right of reproduction, see T. Pihlajarinne, "Should we bury the concept of reproduction - towards principlebased assessment in copyright law?” (2017) 48(8) I.I.C. 953, 961-965.

${ }^{81}$ Svensson, at [24], referring to: SGAE, at [40] and [42]; Divani, at [38]; and ITV, at [39].

${ }^{82}$ Even if the Court has not expressly ruled on this point, in light of the reasoning in Svensson and subsequent case law (including the recent decisions in Renckhoff and Tom Kabinet, on which see below at 'Group (4) cases: unnecessary and misleading role'), it appears quite clear that a rightholder may impose and enforce contractual restrictions to the use and reuse of content published on a certain website, including through linking. Contra, cf. P. McBride, "The "new public" criterion after Svensson: the (ir)relevance of website terms and conditions" (2017) 2017/3 I.P.Q. 262.
}

${ }^{83}$ Svensson, at [25]-[28]. Some commentators have suggested that the requirement that the public targeted by the act of linking be new means overcoming something that, on the side of the relevant rightholder, may be regarded as an implied licence. Of course, this argument holds true if the content made available online and linked to has been published with the consent of the relevant rightholder and is used in accordance with the terms of such licence. Among the first to frame the 'new public' 
In the aftermath of Svensson, as mentioned, the use of the 'new public' as a requirement for a finding of prima facie liability has been particularly criticised. According to some, it would be based on an incorrect interpretation of international law, and would result in an undue exhaustion of the right of communication to the public. ${ }^{84}$

The CJEU confirmed the approach taken in Svensson in the subsequent BestWater order, where it indicated that the provision of a link to content that is technically freely accessible on a third-party website does not fall within the scope of art. 3(1) of the InfoSoc Directive. ${ }^{85}$ In its concise reasoning, the Court failed to address the fact that the content linked to and embedded on the defendant's page had been uploaded and made available without the authorisation of the relevant copyright holder in the first place. The CJEU thus left uncertain the treatment of linking to protected content available on a thirdparty website and first communicated without the consent of the relevant rightholder, i.e. unlicensed content. ${ }^{86}$

Logically, if one followed the reasoning of the CJEU in Svensson to its natural conclusion, then linking of this kind would be always regarded as an act falling within the scope of art. 3(1) of the InfoSoc Directive since there would be always a 'new public': the rightholder never had any public in mind since they had not authorised the making available of the protected content in the first place. The "new public' used in Svensson to exclude the application of art. 3(1) of the InfoSoc Directive to the situation at issue in the background proceedings would, in turn, make any unauthorised linking scenarios not mirroring the factual circumstances at issue in that case fall within the scope of the right of communication to the public.

Yet, when the opportunity arose to address the case of linking to protected content made available without the consent of the rightholder (in GS Media), the CJEU took a different direction: other criteria which, in earlier case law, had been considered though without formally carrying decisive weight notably the knowledge of the link provider of the illegal nature of the underlying communication and the existence of a profit-making intention on their side - did instead gain centre stage. ${ }^{87}$ The CJEU held that the unauthorised provision of a hyperlink to a copyright work that is freely accessible and was initially published without the rightholder's consent on another website does not always result in

requirement within an implied licence perspective, see: J.C. Ginsburg, "Hyperlinking and infringement: The CJEU decides (sort of)" (17.03.2014), available at <https://www.mediainstitute.org/2014/03/17/hyperlinking-and-infringement-the-cjeudecides-sort-of/> (last accessed 30 June 2020); and E. Arezzo, "Hyperlinks and making available right in the European Union - what future for the Internet after Svensson?" (2014) 45(5) I.I.C. 524, 543. The CJEU itself considered the 'new public' requirement from a licensing perspective in Marc Soulier Sara Doke v Ministre de la Culture et de la Communication Premier ministre (C-310/15) EU:C:2016:878, at [36]. According to some, prior to that decision, the Court had already implicitly adopted this perspective in GS Media: see Karapapa, "Defences", cit, fn 16, sub Ch. 3.

${ }^{84}$ Art. 3(3) of the InfoSoc Directive provides that neither the right of communication nor the right of making available to the public may be subject to exhaustion, meaning that the relevant rightholder remains able to control any subsequent acts of communication/making available to the public done in relation to their protected subject-matter also following the initial act of communication/making available to the public thereof. For a criticism of the use of the concept of 'new public' in linking cases, also from the perspective of art. 3(3) of the directive, see: Association Littéraire et Artistique Internationale, "Opinion", cit, fn 9, 2; J. Rosén, "How much communication to the public is 'communication to the public'?", in I.A. Stamatoudi (ed), New Developments in EU and International Copyright Law (Alphen aan den Rijn: Wolters Kluwer, 2016), p. 341-347.

${ }^{85}$ BestWater, at [18]-[19].

${ }^{86}$ Also discussing the interpretative doubts left by the decisions in Svensson and BestWater, see M. Leistner, "Copyright at the interface between EU law and national law: definition of "work" and "right of communication to the public"” (2015) 10(8) J.I.P.L.P. 626, 636.

87 J.C. Ginsburg - L.A. Budiardjo, "Liability for providing hyperlinks to copyright-infringing content: international and comparative law perspectives" (2018) 41 Colum. J.L. \& Arts 153, 169-170, argue that post-Svensson case law might have reduced the centrality of the 'new public' criterion. 
prima facie liability for the link provider. Taking into account multiple elements, the Court differentiated between various situations and introduced a complex liability grid. ${ }^{88}$

In group (3) cases - notably in Svensson - the 'new public' requirement was employed as a substantive requirement to establish whether the activity at issue would fall within the scope of application of art. 3(1) of the InfoSoc Directive. At the same time, such approach also prompted the CJEU, in GS Media, to introduce new or enhance the role of other criteria, the intention being to develop a framework where not only a high level of protection would be guaranteed, but also a fair balance of rights and interests including those in the EU Charter of Fundamental Rights - would be achieved. ${ }^{89}$

\section{Group (4) cases: unnecessary and misleading role}

This final and also most recent group of decisions is one in which the employment of the concept of 'new public' as a requirement was both unnecessary and misleading: the activities of the defendants in the background national proceedings qualified as new acts of communication to the public, which also happened to be directed at a new public. As indicated, the decisions in this group arguably resulted from an incorrect reading of ITV, as well as the experience of group (3) cases: the CJEU moved from the assumption that, any time that the original and the defendant's communication take place on the internet, the technical means used is the same. ${ }^{90}$ As a result, in order to establish prima facie liability in the event that the latter is unauthorised, it would be necessary to consider whether this is in fact a communication to a 'new public'.

However, in ITV, the Court stated that any communication that uses specific technical means serving purposes other than ensuring or improving reception of the original transmission in its catchment area does in principle require the authorisation of the relevant rightholder, not merely communications done using different technical means. ${ }^{91}$ Reasoning that 'same technical means' equals a need for a 'new public', as the CJEU substantially did in group (4) cases, has two implications. First, as stated, it represents an incorrect reading of ITV. Secondly, it could also lead to the undue exhaustion of the right of communication to the public, contrary to the InfoSoc directive (recital 29 and art. 3(3)), if the 'new public' is not construed to mean that the communication is already authorised. The very problematic implications of this incorrect reading, the seeds of which were sown in VCAST (discussed above), became apparent in Renckhoff and Tom Kabinet.

The referral in Renckhoff was made in the context of proceedings concerning the downloading of a photograph, which had been previously published with the limited permission of the rightholder on a website where it was freely accessible, and its subsequent re-uploading and making available on a different website. The question for the CJEU was whether such activity would fall within the scope of application of art.3(1) of the InfoSoc Directive. The Court considered that the defendant's communication, albeit new, had been done using the same technical means as the original communication, that is the internet. ${ }^{92}$ This was interpreted as meaning that the question whether the

\footnotetext{
${ }^{88}$ See E. Rosati, "GS Media and its implications for the construction of the right of communication to the public within EU copyright architecture" (2017) 54(4) C.M.L. Rev. 1221, 1224 also providing a table (first published by the Author on specialist intellectual property blog The IPKat) that summarises the different scenarios considered by the CJEU. The application of the principles established in GS Media in national case law has given rise to uncertainties: see further the discussion in Rosati, "Copyright", cit, fn 29, p. 103-106 and 110-115.

${ }^{89}$ GS Media, at [31], also referring to Charter of Fundamental Rights of the European Union [2012] OJ C 326/391.

${ }^{90}$ Prior to Renckhoff, M. Leistner, "Copyright at the interface between EU law and national law: definition of "work" and "right of communication to the public"" (2015) 10(8) J.I.P.L.P. 626, 634, noted that the definition of the same technical means had been rather generous in CJEU case law: on the internet all potential and different forms of communication appear to constitute the same technical means.

${ }^{91}$ ITV , at [23]-[29].

${ }^{92}$ Renckhoff, at [25].
} 
defendant's communication was also directed at a new public required consideration. ${ }^{93}$ Applying case law on linking (group (3) cases), noted the Court, would run contrary to the requirement of setting a fair balance between different rights and interests, as it is instead required under recitals 3 and 31 of the InfoSoc Directive. ${ }^{94}$ In doing so, the CJEU narrowed down the possibility to apply Svensson and the other group (3) cases to non-linking scenarios. Then, the CJEU considered that the rightholder had only consented to the publication of his work on the initial website. As such, he had only envisaged the visitors of that website as the public at which the communication of his work would be directed, not also users of the website on which the work was subsequently published without their consent, or other internet users. From this it followed that the activity of the defendant would be directed at a 'new public' and consequently fall within the scope of application of art. 3(1) of the InfoSoc Directive.

Whilst reaching the correct result, the reasoning followed in the judgment is unnecessarily complicated and fails to detect a key aspect that differentiates the situation at hand from that at issue in group (3) cases, which the Court referred to: the type of communication at issue. In group (3) cases, the communication performed by the defendant was different in the sense that the provision of links to content hosted on a third-party website was the secondary communication of content already communicated. Hence, the 'new public' was a substantive requirement (at least in Svensson) because it served to determine whether this activity would indeed qualify as communication to the public. In Renckhoff, instead, the defendant's communication was a new 'emission' tout court.

In this problematic respect, Renckhoff has not remained an isolated decision. The CJEU, in fact, followed a similar line of reasoning in Tom Kabinet. This referral was made in the context of litigation regarding the activities of a Dutch business, Tom Kabinet, that traded in second-hand e-books. The referring court had explicitly sought clarification on the interpretation of the right of distribution within art. 4(1) of the InfoSoc Directive, including whether the concept of distribution would encompass the making available remotely of an e-book by means of downloading. In its judgment, as mentioned, the CJEU reformulated the question as asking whether the activity at issue would qualify as an act of distribution or whether, instead, it would qualify as an act of communication to the public under art. 3(1) of the InfoSoc Directive. It concluded that Tom Kabinet's activity would be a communication to the public within the meaning of that provision. ${ }^{95}$ In all this, the Court felt the need to consider whether the public at which the defendant's communication was directed would be 'new'. It did so because, again, it regarded the technical means used for the initial and the defendant's communication as being identical (the internet). It concluded that also this requirement was fulfilled, because of the terms of the licence accompanying the e-books subsequently made available for 'sale' by Tom Kabinet. ${ }^{96}$ However, like Renckhoff, there was no need to consider whether the public at which the communication was directed was new, since Tom Kabinet's communication was, in fact, a new communication to the public.

Overall, the more recent decisions included in group (4) display a further mutation of the role of the 'new public'. The overall misunderstanding of the role and function of 'new public' as, in particular, adopted in ITV has led to the misleading application thereof, in the sense of prompting its consideration as a substantial requirement even in situations where this would not be necessary.

\section{Why has the CJEU been using the concept of 'new public'?}

The Court has used the 'new public' for different purposes in the four groups or phases of cases that have been identified in this article. In group (1) cases, with the exception of Del Corso, the concept of

\footnotetext{
${ }^{93}$ This was also the view of the Land of North Rhine-Westphalia and the Italian government: see Renckhoff, at [27].

${ }^{94} \mathrm{Ibid}$, at [41]. See also M. Favale - M. Kretschmer - P.L.C. Torremans, "Who is steering the jurisprudence of the European Court of Justice? The influence of Member State submissions on copyright law" (2020) 83(4) M.L.R. 831, 844, who refer to Renckhoff as a decision in which the CJEU 'distinguished' the situation at hand from the linking cases which, in this article, are included in group (3).

95 Tom Kabinet, at [65] and [69].

${ }^{96} \mathrm{Ibid}$, at [70]-[71].
} 
new public served the Court to legitimise the application of the communication to the public in the event of further exploitation of a communication originally made by a third party, upon which such further exploitation is premised. In this sense, the 'new public' was not employed as a substantial requirement.

Turning to group (2) cases, ITV was the starting moment for the misinterpretation and misapplication of the 'new public'. As mentioned, in that case the public targeted by the defendant's communication was the same as the public targeted by the original communication. The Court did subsequently refer to the nature of the technical means used in the two communications: if it is the same technical means, then the 'new public' does become a requirement; if it is different technical means, then the question whether there is also a 'new public' is irrelevant. The Court could have expressed more clearly that the issue of the technical means used is relevant not to the requirement that the communication at issue is, in fact, directed at a certain public (a new public), but rather to the requirement that there is a communication to the public in the first place. In ITV, what the defendant had done was to perform a new act of communication to the public, which had also employed different technical means from the original communication. There was no need to consider whether the public targeted by its communication would be new, but only whether, in fact, the communication to the public at issue was new.

The ambiguities of ITV displayed their most problematic effects in group (4) cases, all situations in which the defendant's communication was indeed an independent act of communication to the public that required the specific authorisation of the relevant rightholder. Yet, the CJEU did not focus on this aspect, but did rather follow a convoluted reasoning - the most significant example being Renckhoff to reach the simple conclusion that a new act of communication to the public of protected subject-matter requires, in principle, the authorisation of the relevant rightholder. Instead, the Court moved from the consideration of how, for content that both the claimant and the defendant communicated on the internet, the technical means used was identical; hence, determination of whether the public targeted by the defendant's communication would be in fact new also appeared necessary. There was and there is no need to do so and then find a way to justify - as the Court did in Renckhoff by evoking the concepts of exhaustion, the preventive character of copyright's exclusive rights, the prohibition of formalities why the communication at issue would fall under art. 3(1) of the InfoSoc Directive.

The group of cases in which the 'new public' did instead play a substantial, yet unsatisfactory, role is group (3) cases. To be more precise, Svensson is where the substantial role was apparent, while GS Media is the decision in which the unsatisfactory role of the 'new public' displayed its effects. The unauthorised provision of a link to protected subject-matter is always an act of communication, though it does not always result in liability under art. 3 of the InfoSoc Directive. The 'new public' is the tool that the CJEU used to this end in Svensson, yet without considering the shortcomings that would result from it. Paradoxically, the 'new public' considered to contain and restrict the application of the right of communication to the public in that case would serve to establish potential liability in each and every situation not mirroring the factual scenario at hand in Svensson. To avoid this conclusion, the Court subsequently gave centrality to criteria that, prior to GS Media, were not regarded as decisive (the profitmaking intention of the link provider) or were not part of the assessment under national law in primary/direct infringement situations vis-á-vis secondary/indirect infringement scenarios (the knowledge of the link provider).

In all this, it also appears that use of the 'new public' has in some instances served to water down the traditional distinction between primary (direct) and secondary (indirect/accessory) liability for copyright infringement, as it was inter alia the case in Ziggo. There, the CJEU considered that the operators of The Pirate Bay, an engine for peer-to-peer file-sharing, would be directly liable for copyright infringement. EU legislature has harmonised the conditions for primary (direct) liability, but the existence of and conditions for a finding of liability as a secondary (accessory) infringer have been 
formally left to the legal systems of individual Member States. ${ }^{97}$ While the former is an open-ended set of situations, which have been traditionally assessed from an objective standpoint, i.e. without considering the defendant's state of mind as determinative for the establishment of prima facie liability, the latter requires consideration of the defendant's state of mind. The Opinion of AG Szpunar in Ziggo makes no mystery of both the will and the need - for internal-market building/functioning purposes to find a solution under the harmonised EU primary liability regime, rather than leaving it to individual Member States' secondary liability regimes to address:

The European Commission, whose opinion appears to me to be shared by the United Kingdom of Great Britain and Northern Ireland, contends that liability for sites of this type is a matter of copyright application, which can be resolved not at the level of EU law but under the domestic legal systems of the Member States. Such an approach would, however, mean that liability, and ultimately the scope of the copyright holders' rights, would depend on the very divergent solutions adopted under the different national legal systems. That would undermine the objective of EU legislation in the relatively abundant field of copyright, which is precisely to harmonise the scope of the rights enjoyed by authors and other rightholders within the single market. That is why the answer to the problems raised in the present case must, in my view, be sought rather in EU law. ${ }^{98}$

According to some commentators, since at least the decision in Svensson, the CJEU has embraced an autonomous (EU) concept of liability, which disregards the traditional distinction between different forms of liability. ${ }^{99}$ Even more clearly so, by introducing an express knowledge requirement within the scope of primary liability with GS Media, the CJEU blurred the distinction between what has been traditionally regarded as a strict liability tort (primary/direct infringement) and liability informed by the defendant's subjective state of actual or constructive knowledge (secondary/indirect infringement), and introduced an EU (CJEU) approach to a unitary system of liability for infringement of the right of communication to the public. Ziggo completed this process. ${ }^{100}$

\section{For a (more) meaningful use of the 'new public'}

The analysis of case law, notably the one belonging to group (3), in which the role of the 'new public' has been substantial, suggests that this concept has proved neither helpful nor sufficient. If the CJEU however continues relying on it, is it possible for the concept of 'new public' to be employed in a more meaningful way than what has been the case so far?

As the analysis of groups (2) and (4) cases has shown, consideration in those referrals of whether the public at which the defendant's communication is directed is 'new', i.e. using the 'new public' as a requirement, was both unnecessary and misleading. It was unnecessary because all these cases did concern situations in which the defendant had performed a new communication to the public of

\footnotetext{
${ }^{97}$ For an overview of the different regimes, see G.F. Frosio, "From horizontal to vertical: an intermediary liability earthquake in Europe" (2017) 12(7) J.I.P.L.P. 565, 570. See also M. Leistner, "Structural aspects of secondary (provider) liability in Europe" (2014) 9(1) J.I.P.L.P. 75, 87-90, addressing the question whether common principles of secondary liability may be discerned.

${ }^{98}$ Opinion of Advocate General Szpunar in Stichting Brein v Ziggo BV and XS4All Internet BV (C-610/15) EU:C:2017:99, at [2].

${ }^{99}$ A. Ohly, "The broad concept of "communication to the public" in recent CJEU judgments and the liability of intermediaries: primary, secondary or unitary liability?" (2018) 13(8) J.I.P.L.P. 664, 670-671; J.B. Nordemann, "Recent CJEU case law on communication to the public and its application in Germany: a new EU concept of liability" (2018) 13(9) J.I.P.L.P. 744, 745; Karapapa, "Defences", cit, fn 16, sub Ch. 3; C. Foong, "Volition and the "new public": a convergence of US and EU judicial approaches to communications to the public" (2020) 42(4) E.I.P.R. 230, 233.

100 This approach gives rise to practical uncertainties in those EU jurisdictions that have a secondary liability regime, notably liability by authorisation. See G.B. Dinwoodie, "A comparative analysis of the secondary liability of online service providers" in G.B. Dinwoodie (ed), Secondary liability of internet service providers (New York: Springer, 2017), p. 8, noting that he concept of 'authorisation' in this context is such as to establish "an act of nominally primary liability that clearly maps in substance to conventional forms of secondary or joint tortfeasor liability."
} 
protected subject-matter. As such, even under the (criticised) interpretation of the Berne Convention as provided by the 1978 Guide, there would be no need to consider whether the communication at hand is directed at a public broader than that composed of direct users. What was at issue in those cases was not a behaviour that would exceed the scope of the licence granted by the relevant rightholder, but rather a situation in which no licence had been granted for the use in question in the first place. As such, the rightholder should be in a position to control new communications to the public of their subject-matter. This conclusion complies with the preventive character of copyright's exclusive rights and the prohibition of exhaustion of the right of communication to the public. Consideration of the 'new public' on the side of the CJEU was also misleading (notably for group (4) cases), in that it incorrectly suggested that, where the public targeted by the initial and the defendant's communication is the same, in principle there would be no communication to the public under art. 3(1) of the InfoSoc Directive, when both communications employ the same technical means (the internet). The reasoning in Renckhoff stands in particular as a demonstration that a result of this kind could not be accepted: the CJEU justified the different, correct conclusion by relying on other elements. However, it could have avoided all this simply by acknowledging that the communication made by the defendant was, in fact, a new act of communication to the public. The 'new public' proved insubstantial in group (1) cases, where the emphasis was placed on whether the provision of relevant transmission equipment served the overall profit-making purpose of the defendant. In relation to group (3) cases, with the exception of Svenssonlike scenarios, the Court relied on other criteria to determine applicability of art. 3(1) of the InfoSoc Directive. The 'new public' was not even or at least not the only element to take into account. Consideration of the intention of the defendant, as well as their knowledge, i.e. something which has traditionally fallen within the realm of secondary (indirect/accessory) liability, played a key role.

In light of the foregoing, it is thus submitted that:

- The concept of 'new public' should not be regarded as a requirement in cases where the one at issue is a new act of communication to the public made by the defendant, by that meaning an act of exploitation of protected subject-matter that is independent of or additional to any prior act of communication to the public undertaken by the relevant rightholder. This is so irrespective of whether the technical means used for the initial and latter communication is the same or different and whether the public targeted by the new act of communication is also new.

- In re-transmission and public performance cases, the concept of 'new public' should be corrected, in the sense that it should be considered as an expression of the reasons why the defendant installed physical facilities for enabling or making a communication.

- In linking cases, standing Svensson (the broader applicability of which, in any case, has been scaled down by the CJEU in GS Media itself and later on in group (4) cases), the CJEU should expressly acknowledge - when given the opportunity to do so - that the EU liability regime for infringement of the right of communication to the public is also autonomous and one that, in certain cases, combines concepts that have traditionally been part of the system of primary (direct) liability and concepts that have traditionally been employed in secondary (indirect) liability scenarios, with the de facto result that Member States' approaches should be also uniform in this regard. In practical terms, courts faced with linking scenarios, should consider the 'new public' only in Svensson-like scenarios (linking to freely accessible, licensed content), and avoid considering it as a requirement in cases concerning linking to unlicensed content because no public had been contemplated in the first place. In such instances, the GS Media criteria (knowledge and profit-making intention) are sufficient to determine whether liability could be established.

\section{Conclusion}

This article has analysed CJEU case law on the concept of 'new public' in the right of communication to the public under art. 3(1) of the InfoSoc Directive by identifying four groups of cases. It has detailed the evolution that the concept has undergone and found that it has had different roles in different case groups. 
Overall, the analysis has shown that the only instance in which the concept of 'new public' has played a substantial, though neither decisive (with the exception of Svensson-like scenarios) nor particularly helpful, role has been in group (3) cases. The concept of 'new public' in those instances, as shown in particular in GS Media through the additional criteria of profit-making intention and knowledge on the side of the defendant, has also prompted the Court to incorporate concepts of secondary (indirect/accessory) liability into the EU primary (direct) liability regime. Whilst the proactive stance towards merging concepts of (harmonised) primary and (unharmonised) secondary liability is not entirely surprising, considering the long-standing history of de facto harmonisation of copyright concepts in CJEU copyright case law ${ }^{101}$, it also raises questions of legitimacy and competence. ${ }^{102}$ These have not been addressed in this contribution, though they are relevant, not only to intellectual property, but generally to all areas of the law affected by the process of EU harmonisation. They also stimulate a reflection on what appears to be a divide between the formal and actual allocation of harmonisation and internal market-building roles between the EU legislature and the CJEU.

The analysis undertaken in this article leads to the overall conclusion that the CJEU should at least cease considering the 'new public' as a requirement in instances in which the defendant's act of communication to the public is in fact a new act communication to the public. If that is the case, art. 3(1) of the InfoSoc Directive applies and it is irrelevant whether the technical means is the same or different and whether the public targeted by said act is also new. The one suggested is a solution that is readily implementable without the need to 'depart' from earlier case law. It also allows a more streamlined reasoning on the side of the CJEU, which is respectful of the language, content, and aims of both international and EU law provisions. In sum, the elusive 'new public' concept that has dominated CJEU case law on communication to the public since 2006 may not be as key as the Court has instead considered and conveyed it to be.

\footnotetext{
${ }^{101}$ See, e.g., the discussion in Rosati, "Copyright", cit, fn 29, p. $42-43$ and 73-93 and, with specific regard to the harmonising force inherent to regarding concepts that do not refer to national laws as autonomous concepts of EU law, P. Torremans, "The role of the CJEU's autonomous concepts as a harmonising element of copyright law in the United Kingdom" (2019) 2019/4 I.P.Q. 265 .

102 A. Ramalho, The Competence of the European Union in Copyright Lawmaking - A Normative Perspective of EU Powers for Copyright Harmonization (New York: Springer, 2016), p. 59-60.
} 